\title{
Unexpected Prolonged Neuromuscular Block after Mivacurium: A Case Report
}

\author{
Makani Hemadria Makani Purva ${ }^{c}$ Vesselka Traykova ${ }^{b}$ \\ Departments of a Surgery and ${ }^{\mathrm{b}}$ Anaesthesia, Al-Rashid Hospital, Salmiya, and cDepartment of Anaesthesia, \\ Mubarak-Al-Kabeer Hospital, Jabriya, Kuwait
}

\section{Key Words}

Muscle relaxant $\cdot$ Prolonged apnoea .

Pseudocholinesterase deficiency · Mivacurium

\begin{abstract}
Objective: To present a case of unexpected prolonged apnoea following the administration of mivacurium, a short-acting muscle relaxant and to identify the factors for early diagnosis and management. Clinical Presentation and Intervention: A 19-year-old physically fit lady without personal or family history suggestive of anaesthetic problems had an excision of fibro-adenoma from the breast. She did not recover as quickly as was expected from the anaesthetic, which included the administration of mivacurium. She had prolonged neuromuscular blockade. She was kept ventilated and sedated. Five hours after the last dose of mivacurium, she showed signs of spontaneous respiration and at $6 \mathrm{~h}$ she was extubated and fully recovered. It was shown later that the patient had a pseudocholinesterase deficiency. Conclusion: Pseudocholinesterase deficiency is an uncommon occurrence but should be highly suspected in cases of prolonged paralysis following the administration of a short-acting muscle relaxant. The use of a nerve stimulator is recommended whenever muscle relaxants are used. Muscle relaxants should be used only when facilities for prolonged ventilation are available.
\end{abstract}

Copyright () 2002 S. Karger AG, Basel

\section{KARGER}

Fax +41613061234

E-Mail karger@karger.ch

www.karger.com
(C) 2002 S. Karger AG, Basel

1011-7571/02/0111-0050\$18.50/0

Accessible online at:

www. karger.com/journals/mpp

\section{Introduction}

Mivacurium is a highly selective, short-acting, nondepolarising muscle relaxant with a fast recovery profile and is thought to be ideal for day case procedures. The primary mechanism for inactivation of mivacurium is due to enzymatic hydrolysis by plasma cholinesterase, yielding a quaternary alcohol and a quaternary monoester as metabolites $[1,2]$. We present the case of a 19year-old female patient who underwent an excision of a fibro-adenoma of the breast after the administration of mivacurium as a part of her anaesthetic agents. She had a prolonged neuromuscular paralysis following the use of mivacurium due to a previously unrecognised deficiency of plasma cholinesterase.

\section{Case Report}

A 19-year-old, fit, 70-kg Lebanese female was admitted for routine breast lump excision as a day case. She was pre-operatively assessed to be an American Society of Anaesthesiologists risk grading 1 (ASA 1) patient with no previous anaesthetic experience. She was not on any medication. There was no family history of anaesthetic-related problems.

Anaesthesia was induced with propofol $160 \mathrm{mg}$, fentanyl $100 \mu \mathrm{g}$ and mivacurium $16 \mathrm{mg}(0.2 \mathrm{mg} / \mathrm{kg})$, the patient was intubated uneventfully and anaesthesia was followed with boluses of mivacurium $4 \mathrm{mg}(0.05 \mathrm{mg} / \mathrm{kg})$ and $5 \mathrm{mg}(0.07 \mathrm{mg} / \mathrm{kg})$, at 7 and $16 \mathrm{~min}$, respectively, after the initial dose. The supplements were given with-
Dr. Makani Hemadri

56 Cullingworth Street

Dewsbury WF 13 4AN (UK)

Tel./Fax +44 19240521630, E-Mail mhemadri@hotmail.com 
out waiting for recovery of muscle activity, as it appeared that the procedure might be longer than expected and to avoid any coughing or straining. The total amount of mivacurium used was $25 \mathrm{mg}$, that is $0.35 \mathrm{mg} / \mathrm{kg}$. Supplementary anaesthesia included oxygen, nitrous oxide and increments of propofol up to a total of $300 \mathrm{mg}$. Surgery was completed uneventfully in $25 \mathrm{~min}, 1 \mathrm{~h}$ after the onset of anaesthesia; when the patient did not recover muscle function despite discontinuation of anaesthetics, she was declared to have prolonged muscle paralysis. One hour after the last dose of mivacurium, reversal was attempted with $1 \mathrm{mg}$ neostigmine with $0.6 \mathrm{mg}$ atropine and again $1 \mathrm{~h}$ later with $1.5 \mathrm{mg}$ neostigmine and $0.6 \mathrm{mg}$ atropine. She was kept ventilated with oxygen, nitrous oxide and increments of midazolam to prevent awareness. Serum electrolytes were requested and were found to be normal. No recovery was noted until $300 \mathrm{~min}$ after the last dose of mivacurium when some response was noted as weak spontaneous respiratory efforts. Full recovery occurred with good respiratory activity and sustained head lift, and the patient was extubated successfully at $360 \mathrm{~min}$ from the start of the procedure. Vital signs were stable throughout and the patient was discharged home the next day.

Her serum cholinesterase level, measured postoperatively, was $4,794 \mathrm{IU}$ at $37^{\circ} \mathrm{C}$ (reference values 7,000-19,000). The patient was given a medical alert report and the family was counselled to have a genetic work-up.

\section{Discussion}

Plasma cholinesterase activity may be diminished in the presence of genetic abnormalities of plasma cholinesterase as in the case of patients who are heterozygous or homozygous for an atypical plasma cholinesterase gene. As with suxamethonium, patients homozygous for the atypical plasma cholinesterase gene ( 1 in 2,500 patients) are extremely sensitive to mivacurium. The manufacturer's leaflet draws attention to 3 such adult patients, where mivacurium $0.03 \mathrm{mg} / \mathrm{kg}$ (approximately the $\mathrm{ED}_{10-20}$ in genotypically normal patients), produced complete neuromuscular block in 26-128 $\mathrm{min}$ [2]. The duration of block has been found to be variable with similar doses producing much longer periods of block [3-6]. Bell [5] reported a case where $0.18 \mathrm{mg} / \mathrm{kg}$ of mivacurium was used and the patient had $80 \mathrm{~min}$ of neuromuscular block. Ogunbiyi and Branch [4] had a block lasting 270 min using a dose of $0.1 \mathrm{mg} / \mathrm{kg}$ mivacurium. Petersen et al. [6] used $0.12 \mathrm{mg} / \mathrm{kg}$ of mivacurium and reported 370 min of neuromuscular paralysis, and Vanlinthout et al. [3] had $450 \mathrm{~min}$ of blockade with just $14 \mu \mathrm{g} / \mathrm{kg}$ used as a test dose. All these patients were homozygous for the atypical plasma cholinesterase gene. It has been suggested that a test dose of mivacurium could help in identifying susceptible patients, but this is not foolproof either as even a test dose can induce prolonged paralysis [3]. A careful family history should reveal any inherited defi- ciencies of the enzyme, but in cases like ours where there was no such history, prolonged apnoea can be an unexpected event [4].

Spontaneous recovery from the effect of mivacurium is rapid, so reversal agents may not be required routinely. We used a total of $25 \mathrm{mg}$ mivacurium spread over $15 \mathrm{~min}$, which, in a normal 70-kg patient, should enable approximately $38 \mathrm{~min}$ of relaxation. However, in our patient it lasted $6 \mathrm{~h}$. It is believed that the anticholinesterase reversal agent neostigmine can actually prolong the duration of action of mivacurium and therefore should be given only when most of the neuromuscular activity has returned [7]. Neostigmine was used in our case at 1 and $2 \mathrm{~h}$ after the last dose of mivacurium as the diagnosis by exclusion was made at that stage. Since the dose used was small and sufficient time had elapsed since the last dose of mivacurium, we do not think that it could have contributed to the prolonged duration of the block [7]. However, the use of a peripheral nerve stimulator could have helped in making the diagnosis earlier and perhaps avoided the boluses of mivacurium that were administered after the first dose [4]. The plasma cholinesterase level in our patient was $68 \%$ of normal, suggesting that the patient could be heterozygous for the plasma cholinesterase gene.

Prolonged apnoea following mivacurium is a very uncommon occurrence and therefore requires a high index of suspicion to diagnose it. However, management is relatively simple, consisting of elective ventilation until the patient recovers and use of anaesthetics to avoid awareness. It is important that electrolyte abnormalities that may prolong neuromuscular paralysis are corrected. Human plasma cholinesterase has been used to overcome mivacurium apnoea, but it is expensive and requires special manpower; hence, it will not be feasible in the near future [8].

Drug interactions should be sought after and excluded. Metoclopramide [9], a commonly used perioperative drug, is one among some of the drugs that decrease the plasma cholinesterase activity and produce unexpected apnoea. Certain antibiotics, antidepressants and anti-arrhythmic drugs may also prolong the effect of muscle relaxation. Our patient was not on any such medication, but women are believed to be more sensitive to neuromuscular blocking drugs than men [9].

Our case draws attention to the difficulties that arise in the setting of an ASA 1 patient requiring an additional stay, which involves costs to the patient and the hospital. The family suffers great trauma after what should have been a simple operation. It is reasonable to suggest that where mivacurium is used, there should exist facilities for 
prolonged ventilation. The Royal College of Anaesthetists' practice guidelines suggest that nerve stimulation monitoring should be performed for all cases where muscle relaxants are used [10]. It is believed that cautious use of neostigmine under neuromuscular monitoring might aid in the early recovery of these patients [5]. Hence a nerve stimulator is highly recommended for monitoring the need for avoidable top-up administration and for diagnosing and treating unexpected cases of apnoea following muscle relaxants.

Counselling patients and relatives enables documentation of the diagnosis of the condition and hence any anaesthetist in the future will be forewarned. A detailed genetic mapping to assess if the patient is homozygous or heterozygous and a complete assessment of plasma cho- linesterase activity in the form of dibucaine and fluoride numbers will be needed [6]. The family also needs to be screened with similar studies to identify potential cases.

\section{Conclusion}

This case report raises the important question as to the continued use of mivacurium, especially in the setting of day care centres. Perhaps other muscle relaxants that have a better track record could be used. Since at the moment it is not practical to screen all preoperative cases for pseudocholinesterase deficiency, we recommend that nerve stimulators be used to monitor patients who receive muscle relaxants as a part of their anaesthetic.

\section{References}

1 Savarese JJ, Ali HH, Basta SJ, et al: The clinical neuromuscular pharmacology of mivacurium chloride (BW B1090U). Anesthesiology 1988;68:723-732.

2 Product information: Injection Mivacron. London, Wellcome Foundation Ltd, 1/5568 (E/Ar) 94.09.

3 Vanlinthout LE, Bartels CF, Lockridge O, Callens K, Booij LH: Prolonged paralysis after a test dose of mivacurium in a patient with atypical serum cholinesterase. Anesth Analg 1998; 87:1199-1202.
4 Ogunbiyi OA, Branch KG: Mivacurium apnoea: A trap for the unwary. Int J Clin Pract 1999;53:154-155.

5 Bell M: Reversal of mivacurium apnoea with neostigmine. Anaesthesia 1994;49:350.

6 Petersen RS, Bailey PL, Kalameghan R, Ashwood ER: Prolonged neuromuscular block after mivacurium. Anesth Analg 1993;76:194196.

7 Savarese JJ, Lien CA, Belmont MR: Antagonism of residual mivacurium blockade: Setting the record straight. Anesthesiology 1996;84: 1525-1528.
8 Naguib M, el-Gammal M, Daoud W, Ammar A, Moukhtar H, Turkistani A: Human plasma cholinesterase for antagonism of prolonged mivacurium-induced neuromuscular blockade. Anesthesiology 1995;82:1288-1292.

9 Skinner HJ, Girling KJ, Whitehurst A, Nathanson $\mathrm{MH}$ : Influence of metoclopramide on plasma cholinesterase and duration of action of mivacurium. Br J Anaesth 1999;82:542-545.

10 Royal College of Anaesthetists: Guidance on intraoperative care/Guidelines for the provision of anesthetic services, p 18. http:// www.rcoa.ac.uk/DLOAD/GLINES.pdf 